AWEJ for Translation \& Literary Studies, Volume 4, Number4. October 2020

Pp. 187-201

DOI:http://dx.doi.org/10.24093/awejtls/vol4no4.13

\title{
From Feminization of Fiction to Feminine Metafiction in Gaskell's Wives and Daughters and Woolf's Orlando
}

\author{
Wassila HAMZA REGUIG MOURO \\ LLC Lab \\ Department of English, Faculty of Letters and Languages \\ University of Aboubekr Belkaid, Tlemcen, Algeria
}

\begin{abstract}
Feminism developed and widened its scope to different disciplines such as literature, history, and sociology. It is associated with various other schools and theories like Marxism and poststructuralism, as well. In the field of literature, feminist literary criticism managed to throw away the dust that cumulated on women's writing and succeeded in raising interest in those forgotten female artists. Some critics in the field of feminism claim that there are no separate spheres, masculine and feminine, whereas others have opted for post-feminist thinking. Some women writers used metafiction to write literary criticism. Therefore, how do Gaskell and Woolf implement metafiction in their stories? Accordingly, this work aims at shedding light on Wives and Daughters by Gaskell and Orlando by Woolf to tackle metafiction from a feminist perspective. Examples from both novels about intertextuality, narration, and other aspects, that are part of metafiction, will be provided to illustrate how and where metafiction is used.

Keywords: Feminism, feminist literary criticism, intertextuality, metafiction, narration, Orlando, Wives and Daughters
\end{abstract}

Cite as: HAMZA REGUIG MOURO, W. (2020). From Feminization of Fiction to Feminine Metafiction in Gaskell's Wives and Daughters and Woolf's Orlando. Arab World English Journal for Translation \& Literary Studies 4 (4) 187-201. DOI:http://dx.doi.org/10.24093/awejtls/vol4no4.13 
AWEJ for Translation \& Literary Studies Volume, 4 Number 4. October 2020

From Feminization of Fiction to Feminine Metafiction

HAMZA REGUIG MOURO

\section{Introduction}

Gaskell in Wives and Daughters and Woolf in Orlando criticised the development of fiction, and particularly the novel. Through their literary critique, they discussed the impact of literary genres and movements on each other. For instance, some characters are the epitome of early fiction, the Romantic and Realist movements. Yet, what seems to be interesting is that both novelists, unquestionably, make the link between the rise of the novel, the development of fiction, and women's writings. Therefore, "Gaskell and Woolf do not stop at metafiction but they feminize it. Thus, both novelists show the importance of women's writing in literature throughout the development of their main characters." (Mouro, 2014, p.172)

In Wives and Daughters and Orlando, Gaskell and Woolf, respectively, did not stop at the mere reflection of daily life. They made "the direct link between reality and fiction and represented this dichotomy in the daily lives and struggles of their main characters through their metafiction." (Mouro, 2014, 173)

Looser argues that "women's writing in genres other than fiction has received markedly little attention" (Cited in Price, 2012, p. 262) for it was not a woman's business (Cited in Watson, 1996). Therefore, how can a woman writer even think of producing criticism without being shot down by men? Gaskell wrote criticism under the disguise of fiction. In other words, she wrote fiction about fiction. However, Woolf's time was different from that of the Victorians. She was solicited to give her perspective on literature in general and on fiction precisely as a critic. Hence, Women started to have a few other privileges in their society, and among these, the recognition of women writers.

\section{Literature Review}

In this research paper, a short definition of metafiction along with intertextuality and narration is needed to fully understand the analysis of the selected novels. Women's writing and feminist literary criticism will be discussed briefly as they are directly linked to the analysis.

\section{Metafiction}

Lodge (1992) simplified the definition of metafiction, stating that it "is fiction about fiction" (p. 206). It has been first coined by Gass and developed later on with the studies of many other literary critics. Metafiction highlights the self-reflexivity the narrative and draws the attention of the reader to the fictionality of the work (Waugh, 1984). Furthermore, when a work of fiction goes beyond its original aim which is to tell a story, this is metafiction. Curie (1995) defined it as follows: "the borderline discourse, a kind of writing which places itself...between fiction and criticism" (Cited in Orlowski, 2017).

Orlowski (2017) asserts that metafiction "often employs intertextual references and allusions by... creating biographies of imaginary writers, presenting and discussing fictional works of an imaginary character." Thus, there are many concepts that are linked to metafiction. For the needs of this research, the focus will be on intertextuality and narration.

Arab World English Journal for Translation \& Literary Studies 
Intertextuality

Intertextuality is "the subtle interplay of writing and rewriting" (Mouro, 2013, p. 37). Kristeva reached the idea of intertextuality while studying Bakhtin's (1981) polyphony and dialogism (Cited in Achour and Bekkat, 2002). She considered every text as 'a mosaic of references to other texts, genres and discourses. Every text or set of signs presupposes a network of relationships to other signs like strings that have lost their exact references' (Kristeva, 1986, p.37). Therefore, no text is original as Barthes (1977) explains: "A text is...a multidimensional space in which a variety of writings, none of them original, blend and clash. The text is a tissue of quotations... The writer can only imitate a gesture." (p. 146).

There are several ways of implementing intertextuality in a literary work, such as integration, allusion, collage, citation or parody.

Narration

As explained by Fludernik (2009), the act of narrating is part our daily lives; it is 'an unconscious spoken language activity which can be seen to include a number of different texttypes ... in addition to ... literary narrative as an art form' (p.1). In fiction in general, and novels in particular, the narrator can be omniscient (partly or completely) and here we talk about third person point of view. Alternatively, he/she can be a character and the first person point of view is used in this case.

In metafiction, the intrusive narrator is used as a technique to involve the reader. At times, the narrator/author may intrude 'to comment on writing', or to address the reader (Lodge, 1992, p. 207), calling for his attention 'to the activity of writing as an event within the novel, as an event of equally great significance to that of the events of the story which he is supposed to be telling' (Hutcheon, 1980, p. 12).

\section{Women's Writing}

Thanks to feminist literary criticism, women's writing developed and widened its scope. Lazar (2007) claims that the aim of feminist critical discourse analysis is 'to create critical awareness and develop feminist strategies for resistance and change' (p. 145). Once feminism developed, some women literary researchers tried to take off dust from those lost women writers of the past. Therefore, feminist literary criticism went through two waves. The first one was the re-discovery as claimed by Showalter (1998), in which those women critics re-discovered the works of women writers and brought them back to light. The second wave shifted its interest to recover, historicise, interpret and re-evaluate women's writing (Lorraine, 2000).

"Subordination, protest and autonomy" were the three phases that women's writing went through (Showalter, 1998). In their novels, women writers developed from being imitators in style to initiators of new literary techniques. The feminist literary critics discovered that women moved from being submissive in their writings, to protesting to end up gaining their autonomy and gaining a literary identity.

Arab World English Journal for Translation \& Literary Studies 


\section{Feminine Metafiction in Gaskell and Woolf}

Wives and Daughters and Orlando contain many literary references to poets, novelists, fictional heroes and heroines, and sometimes even passages taken from literary works. Almost all the literary references are in close relation to the heroine Molly Gibson and Orlando.

Right from the beginning, Woolf refers to her protagonist Orlando as a writer, a poet, and playwright. Various literary references and figures are closely related to Orlando. Woolf, through the biography of her protagonist, is writing the biography of a genre, notably that of fiction.

Wives and Daughters begins as a fairy tale. The narrator introduces Molly and her story this way: "To begin with the old rigmarole of childhood. In a country there was a shire ... [...] there lay a little girl" (Gaskell, 1986, p. 35). As soon as 'fairy tale' is pronounced, the reader is automatically waiting for a prince charming to rescue the princess who is in danger. Yet, this is not a fairy tale. It is rather the story of the everyday life of a young girl living in Hollingford village. The researcher may consider that this is an allusion. Still, this fairytale-like introductory paragraph reinforces the idea that we are waiting for a princess and a prince charming. In fact, Gaskell opens her novel with 'the discourse of a children's story' and introduces Molly as a young girl going for a visit to the Grand House at the Towers, "she travels in a carriage to the grand event, and enters an enchanted world" (Foster, 2002, p. 165). Poor little Molly is so exhausted that she sleeps and is forgotten at the Towers by her mother's friends; the Brownings. When Molly wakes up, she is afraid and feels abandoned. Lord Cumnor (owner of the house) speaks to her in a tone that she believes is full of anger, whereas in reality, he was imitating the

deep voice of the fabulous bear, who asks this question of the little child in the story; but Molly had never read the 'Three Bears' and fancied that his anger was real...Lord Cumnor was very fond of getting hold of what he fancied was a joke...he kept on his running fire at Molly, alluding to the Sleeping Beauty, the Seven Sleepers, and any other famous sleeper that came to his head. (Gaskell, 1986, p. 53)

Through this passage, Gaskell not only provides the reader's imagination with the setting of a fairy tale with references to famous tales, but also adds to it the atmosphere with her detailed description as explained in the following example:

She [Molly] lost all consciousness of herself by-and-by when the party strolled out into the beautiful grounds, the like of which she had never even imagined. Green velvet lawns, bathed in sunshine, stretched away on every side into the finely wooded park...there were divisions and ha-has between the soft sunny sweeps of grass, and the dark gloom of the forest-trees beyond... and the melting away of exquisite cultivation into the wilderness had an inexplicable charm to her. (Gaskell, 1986, p. 45)

This detailed description, which is, actually, characteristic of the Victorian novel, gives way to the reader to feel free in his/her imagination to complete what is left unfinished by the tale of the 
narrator. Blair (2007) argues that Gaskell's use of detail "is to indicate motivations that she leaves unexplained, thereby inviting the reader to formulate a critique" (p. 73). The critique is formulated upon the fairytale-like beginning and all that it implies as development in the mind of the reader later on. We may, then, talk of parody, the type of parody that is used by metafictionists, not to make fun of a work of art but rather to criticise through it - and here in this case to discuss fairy tales - as explained by Waugh (1984).

It seems that Gaskell is questioning these fairy tales, which instilled in the minds of people the need for a prince charming to rescue the pretty princess who is in trouble. Therefore, if we go further in our analysis and consider Cynthia as the beautiful princess, it is not Mr Preston, albeit handsome and horse-riding gentleman, who is going to save her. On the contrary, he is the one to put Cynthia in trouble, and it is Molly, her stepsister, that rescues her from the hands of that charming man (Stoneman, 2007).

In fact, through Molly rescuing Cynthia, Gaskell shows that time has changed and that there is no need for a man to save the woman. Indeed, if we follow this idea, man is represented as a source of trouble for the woman. Preston put Cynthia in danger, and because Molly wanted to save her from his grip, she, too, finds herself in a turmoil of scandals. Furthermore, Molly's father gets married as an attempt for him to have a feminine touch at home for his motherless daughter. In fact, this rather hasty 'male' decision causes more sadness and disappointment to both father and daughter than the intended quietness at home. Another example of a man as a source of problems rather than relief is Roger. In reality, Roger Hamley has been a good friend to Molly, and he helped her a lot when she needed him. Yet, when he meets Cynthia, he immediately falls in love with her and totally forgets about his old friend Molly. This situation is unknown to Molly, who feels desperate and does not know what to do. Gaskell seems to call for solidarity between women. She uses "realist detail that allows her to focus on women's everyday lives and to test the limits of Victorian descriptions of femininity" (Blair, 2007, p. 109). Through these women's intertwined stories, Gaskell questions and defies Victorian patriarchal norms and values calling, then, for feminine solidarity. She is known for her solidarity and encouragement of other women writers that are beginners (Foster, 2002).

Woolf's whole novel seems to be a parody, the parody of biography. The latter provides many narrative layers that put the reader into a bewildered state if $\mathrm{s} / \mathrm{he}$ misses one layer. Right from the beginning of the novel, we understand that Woolf's objective is to write the biography of Orlando. Yet, it is impossible for a human being to cross and live through three or four centuries. Through this parody of biography, Woolf questions the techniques used by the biographer to talk about the life of his character (biographers were mostly men until in the eighteenth century when women started to write and inscribe their names as women writers). Woolf questions the kind of 'truth' that these biographers claim to present and provide the audience with. Westman (2001) calls Orlando a "mock biography'; she believes Woolf "satirically mocks the failures of biography and novels to capture the 'granite' and the 'rainbow' of individuals' lives" (p. 39). Hutcheon's explanation of the role of parody is quite different. For her, a parody is an 'imitation with critical difference' which will allow the two texts to be put on the same stylistic plane and discuss 
intertextually and dialogically (Cited in Peters, 2002). Orlando is a kind of metabiography, a biography of biography where she suggests new ways of writing this genre.

Another example of parody is that of fairy tales, wherein Orlando meets Shelmerdine, her prince charming on his horse, but he almost killed her instead of saving her, for he almost walked on her as she was sitting on the grass;

'The horse was almost on her...she saw a man on horseback. He started. The horse stopped.

'Madame', the man cried, leaping to the ground, 'you're hurt!'

'I'm dead sir!' she replied.

A few minutes later they became engaged' (Woolf, 1975, p. 176).

Through this parody, Woolf questions the way in which fairy tales were written. The prince charming on his horse came, and no matter what he did, even if nothing except asking how the princess is, had the privilege to be loved by that princess and marry her. In fact, what Woolf does a few paragraphs later is to play with the roles of both male and female, between Orlando and Shel. This role reversal, in 'you're a woman, Shel!' she cried / 'you're a man, Orlando!' he cried" (Woolf, 1975, p. 177), represents what lots of feminists tried to show, and among them Simone de Beauvoir (and maybe more than any other), when she explained that being a 'woman' is a man's invention in order to keep the woman in her place. She argues that women are "constrained to operate as man's other", and therefore, this lack of subjectivity enslaves them (Cited in Fallaize, 2007, p. 88).

\section{Techniques in Implementing Metafiction by Gaskell and Woolf}

There are several techniques used by novelists to write metafiction. The following points deal with some of them:

\section{The Use of Intertextuality}

Gaskell (1986) alludes to literary forms. She speaks about fairy tales, poetry, and, novels, as well as the problems of publication embodied in the difficulty Osborne Hamley faces to publish his collection of poems. He asks his brother Roger to try since the latter has a name in Cambridge. According to this last statement, i.e., to have a name in Cambridge, Gaskell refers to publishers who do not publish a work on the grounds of its worth, but on who produces that particular work of art. Furthermore, Hughes and Lund believe that "Gaskell's negotiations with editors and publishers" are represented indirectly through the struggles of Osborne to sell his poems (Cited in Felber, 2001, p. 325).

Through this same character, Gaskell, as well, has created a fictional writer, Osborne Hamley, and she is, therefore, writing his biography. She tells us about his childhood, his struggles at university, his secret marriage, and then about his death.

Arab World English Journal for Translation \& Literary Studies 
Woolf employs quite the same strategies in creating a fictional writer who is Orlando himself (then later on herself). The reader follows the narrator, who is supposed to be the biographer of Orlando, narrating about his childhood, his different life journeys, his change of sex, and her marriage and publication of her poem The Oak Tree.

Woolf, too, speaks about publication struggles, mainly for women to publish. Orlando realized that she was a woman writer in a masculine world, she cries for she knows that the majority of writers are "all so manly...so how can I be a critic and write the best English prose of my time?" (Woolf, 1975, p. 202). Woolf emphasises the fact that women had little opportunity to be read and therefore claim fame. In the same token, Ballaster (2010) argues that "women were less often deterred from writing by sexual double standards on attacks on their virtue that they were from publishing the works they penned" (p. 8). Consequently, Orlando appears in society as a man. She attends literary circles so that her writings can be read and admired by the audience, thinking they are the product of a man:

She found it convenient at this time to change frequently from one set of clothes to another. Thus she often occurs in contemporary memoirs as 'Lord' So-and-so, who was in fact her cousin; her bounty is ascribed to him, and it is he who is said to have written the poems that were really hers. (Woolf, 1975, p. 155)

Orlando hides behind man's clothes to reach her goal of being read and admired by an audience composed of men.

\section{Narration}

One of the features of metafiction is 'to violate narrative levels' as when the writer intrudes to directly address the reader (Orlowski, 2017). Right from the beginning, Gaskell determines the period in which she sets her story, and from time to time, she steps outside her narration to remind us of the time dimension. For instance, when Molly went to Hamley Hall for a visit, she noticed that the furniture is old-fashioned, and Gaskell keeps repeating this expression and contrasts it with her time, as if to remind the reader that this is fiction:

Molly hurried to...arrange her few clothes in the pretty old-fashioned chest of drawers...All the furniture in the room was old-fashioned...the chintz curtains were Indian calico of the last century - the colours almost washed out...There were none of the luxuries of modern days; no writing-table. (Gaskell, 1986, pp. 95-6)

Gaskell shows her reader that she is telling a story that happened forty years before the beginning of her novel. She keeps referring to the period of the story being different from the period in which she writes the story, i.e., the period she really lives in.

Within the first pages of her novel, Woolf provides the age in which the story is set. She describes this Elizabethan Age and compares it with her own time, 
It was Orlando's fault perhaps; yet, after all, are we to blame Orlando? The age was the Elizabethan; their morals were not ours; nor their poets; nor their climate; nor their vegetables even. Everything was different (...) The flower bloomed and faded. The sun rose and sunk. The lover loved and went. And what the poets said in rhyme, the young translated it into practice. Girls were roses and their seasons were short as the flowers. (Woolf, 1975, pp. 18-19)

Woolf keeps comparing the Elizabethan age, i.e., the time of fiction, with the real time - her time of writing the novel, therefore reminding the reader that what she is writing is not reality but fiction: calling the reader to the novel's fictionality. Woolf keeps using the past tense when she refers to the Elizabethan age and provides a kind of parallel with her age. Metafiction writers use this technique to attract the attention of the reader, to remind her/him that the story s/he is reading is fiction and not reality.

This technique, of always reminding the reader that this is a story which took place at a different time, is what Orlowski (2017) defines as 'refusing to become 'real life", as well as 'subverting conventions to transform 'reality' into a highly suspect concept'. For, as long as Gaskell and Woolf keep reminding the reader of the different time dimensions concerning their respective stories, and the period of their writing, the reader is made aware that what s/he is reading is a story and not 'reality'. S/he becomes suspicious about the amount of 'reality' in the events narrated, and that is in fact what is meant by metafiction in drawing attention to the fictionality of the literary work the reader is reading.

A little further, Gaskell discusses poetry and writing - writing which she has already referred to with 'writing-table' (in the above-mentioned quotation). Mrs Hamley praises the poetry of her son Osborne and reads some of the poems out to Molly. She keeps discussing poetry and compares her son's literary productions to Mrs. Hemans' and believes them to be as good as hers: "I think I must read you some of Osborne's poetry...I really fancy they are almost as good as Mrs Hemans" (Gaskell, 1986, pp. 96-97). Here, there is a comparison between a real figure - a historical one - and a fictional character, whose purpose is to root fiction in the space of history. The author relates the text to the content and confirms her first intention to question her society. the novel:

Early in her novel, Woolf links her hero Orlando to writing and says at the beginning of

Soon he had covered ten pages and more with poetry. He was fluent, evidently, but he was abstract. Vice, Crime, Misery were the personages of his drama; there were Kings and Queens of impossible territories; horrid plots confounded them; noble sentiments suffused them; there was never a word said as he himself would have said it, but all turned with a fluency and sweetness which, considering his age - he was not yet seventeen - and that the sixteenth century had still some years of its course to run. (Woolf, 1975, p. 11)

Arab World English Journal for Translation \& Literary Studies 
In this passage, Woolf seems to provide literary criticism of what was written in the sixteenth century. Evidently, according to her, these writings were in verse. Orlando, too, wrote poems and drama. One feels that she is not only referring to the famous playwrights Shakespeare and Marlowe, but she even hints at epics and romances where kings and queens were the chief personages of these literary genres.

Briggs (2006) claims that Woolf had difficulties with Shakespeare, not questioning his talent as a writer, but she could not manage to figure out whether he wrote for men or women. Woolf associated his expression of feelings and imagination to women and his intellect and literary achievement to men, a masculine field, since there were no women playwrights to compete with him. Therefore, we can consider Orlando as the epitome of Shakespeare himself at the beginning of the novel. Briggs (2006) speaks in this case of "an act of homage to Shakespeare" (p. 16).

In the same passage provided earlier from Wives and Daughters, Mrs Hamley asks Molly about poetry and reflects on the writings of her son Osborne. Gaskell steps outside her role of narrator to directly address the reader and explains what is meant by her character Mrs. Hamley, who compares her son's poems to those of Mrs Hemans "to be nearly as good as Mrs Hemans' was saying as much to the young ladies of that day, as saying that poetry is nearly as good as Tennyson's would be in this" (Gaskell, 1986, p. 97). Gaskell, in this passage, comments on the writings of Mrs. Hemans and claims that they are as good as those of Tennyson. Not only is she commenting on writing, but she is, also, making a comparison between a woman and a man writer. For Gaskell, there seems to be no difference in writing related to the gender of the writer; they are comparable and thus equal.

Lodge (1992) clarifies that the violation of the conventions of a narrative is not only by addressing the reader, but by intruding "to comment on writing" (p. 207), as well. When Osborne fails at university and is overwhelmed by debts, he decides to collect his poems to sell them:

He sat down near the fire, trying to study them [his poems] with a critical eye, to represent public opinion as far as he could. He had changed his style since the Mrs Hemans' days. He was essentially imitative in his poetic faculty; and of late he had followed the lead of a popular writer of sonnets. He turned his poems over: they were almost equivalent to an autobiographical passage in his life. (Gaskell, 1986, p. 299)

Here, Gaskell discusses writing and poetry precisely. She claims that he is rather imitative, and his poems sound autobiographical. In fact, not only is Gaskell commenting on her character's poems, but also she is reflecting on the poetry of the early years of the nineteenth century. For her, it seems, the poets of that period were rather imitative and they held an autobiographical aspect in their writings. This, indeed, appears to be the feature related to the late romantic poets who turned to be highly individualistic.

Arab World English Journal for Translation \& Literary Studies 
The death of Osborne Hamley, the poet, does not represent the death of a character in the novel only. Gaskell emphasised the fact that the nineteenth century was no longer an age for poetry and verse in general, but for prose and novel writing precisely.

Another example of commenting on writing is when Lady Harriet, the Cumnors' daughter, tries to find a word to express her idea to Molly Gibson; she looks for it in Maria Edgeworth's work. Gaskell comments on the writings of Miss Edgeworth through her character Lady Harriet:

Oh! That shows you've never read Miss Edgeworth's tales; - now, have you? If you had, you'd have recollected that there was such a word... If you've never read those stories, they would be just the thing to beguile your solitude - vastly improving and moral, and yet quite sufficiently interesting. (Gaskell, 1986, p. 196)

Gaskell, in this quotation, comments on and thus criticises Maria Edgeworth's writing. She qualifies the tales as 'vastly improving and moral.' Gaskell is, again, making use of intertextuality by linking the fictional characters to real historical figures. Blair (2007) discusses these intertextual references and assumes that Gaskell shows "the necessary sisterhood of women in face of male history" (p. 87). Blair develops paragraphs on Gaskell's reference to 'poor Jeanie' who is used by Christina Rossetti in her poem 'Goblin Market' (1862). Therefore, Gaskell highlights the fact that there should be solidarity between women. Blair ends up her intertextual analysis saying that 'remembering Jeanie' reminds the reader of the necessity of negotiating with men's texts and men's images of women.

At the level of writing techniques, Elizabeth Gaskell talks about narration and of the fact that when a writer narrates, s/he is aware of a 'critical listening' (Blair, 2005), which prevents her/him from expressing her/his mind freely. After her return from the Towers, Molly knows that her step-mother is jealous of her visit to the grand house; therefore she selects what happened in such a way as 'to spoil' her narration and avoid her step-mother's replies (Gaskell, 1986). In this passage, we have the shift of narration from the omniscient narrator to the narrator/character embodied by Molly Gibson.

Woolf comments on writing, on biographers, and the different literary productions throughout the centuries crossed by Orlando. Woolf (1975), in the following passage, defines what society is and what composes it and explains that poets and novelists are better equipped to represent society in their writings:

Society is the most powerful concoction in the world and society has no existence whatsoever. Such monsters the poets and novelists alone can deal with; with such something-nothings their works are stuffed out to prodigious size; and to them with the best will in the world we are content to leave it. (p.136)

Yet, by the end of her passage, Woolf seems to be ready to leave society to those novelists and poets and their voluminous literary productions. Instead, as she explains through Orlando later on 
in the same chapter, Woolf (1975) seems to be much more interested in life than in society, and she even attacks those long domestic novels that gave too much importance to society, social classes and materialism leaving life on the margin.

The way Woolf tackles the marriage of Orlando in a mock way reveals her refusal to submit to 'the spirit of the age,' though Orlando herself does. Woolf's criticism of the Victorians resides in skipping details about daily life that are so much present in nineteenth-century novels that they become voluminous. Life for Woolf is the sole interest of the novelist and the biographer. She states; "life, it has been agreed by everyone whose opinion is worth consulting, is the only fit subject for novelist or biographer" (Woolf, 1975, p. 188).

When Orlando is happy receiving Pope, Addison and Swift, Woolf intrudes to provide the reader with passages from their literary works then comments on them. She (1975) asks the reader:

Is he not clear to the very wrinkle in his stockings? Does not every ripple and curve of his wit lie exposed before us, and his benignity and his timidity and his urbanity and the fact that he would marry a Countess and die very respectably in the end? (p. 148)

In this quotation, Woolf joins her idea that she had already formulated on Addison: he is clear, direct, a keen observer, and understood by everyone. Yet, Woolf questions this simplicity; whether it will keep him alive 'as long as the English language' is alive as claimed by Macaulay whom she quotes at the very beginning of her essay. Woolf seems to have done her research on the matter. Only two people per year go to the libraries to have Addison's Tatler and/or Spectator. She believes he is a vanishing literary figure, too clear to raise interest in the reader.

Later on in the novel, Woolf (1975) directly discusses the characteristics of a good writer. She explains that "we write, not with the fingers, but with the whole person. The nerve which controls the pen winds itself about every fibre of our being, threads the heart, pierces the liver" (p. 171). In this passage, Woolf explains the mechanism of literary production. She explains that a writer puts his soul into writing, and that is not mere scratching on a paper.

\section{Fictional Characters/Historical Figures}

One of the other features of metafiction is the juxtaposition of fictional characters and historical figures. This feature is illustrated by the presence in Wives and Daughters of two spinster sisters called Browning. This is a hint at Mr and Mrs Browning, and Molly Gibson lives with them for a while, too. The Browning sisters are different; the eldest is tough and engages herself in trade, and does 'manly activities,' whereas the other is frail, fragile, sentimental, and over-emotional, yet Gaskell does not provide situations or discourse enough in order to say whether this is only a technique of metafiction or rather a criticism of their writings.

Another instance of this real/fictional character juxtaposition is Lady Harriet, who is in close contact with Molly Gibson. Thanks to Harriet's intervention, Molly recovers her reputation, 
and the scandal turning around her vanishes. In a conversation between the two, Harriet asks Molly to read fiction written by Miss Edgeworth, whose fiction is highly moralising

Woolf's technique in juxtaposing real historical/literary figures with fictional ones appears at the beginning of the novel when Orlando meets Queen Elizabeth. His life seems to be linked to the Queen as the latter likes him from the first moment she meets him and proclaims him Steward. In fact, through the juxtaposition of these two types of characters, real and fictional, Woolf is criticising English society during the Elizabethan age and commenting on the Queen herself.

We can consider Orlando as a historical novel because of the numerous historical references on top of literary ones. We can then speak of metahistory: a mixture of history and fiction with a feminist emphasis. Heilmann and Llewellyn (2007) explain metahistory as "a process of critique; their authors seek through the very act of writing to deconstruct and reinterpret aspects of historical processes which have previously been silenced or closed to their female subjects" (p. 2). A woman could not write on history during the Elizabethan Age, nor later on. Woolf mixes history with her fiction in order to interpret it from a feminine perspective.

When Orlando changes to a woman, she decides to go back to her home country. Women's status in England was better than in other countries. On her way back to England, Orlando reflects on the fact that if she were born a girl, as a child, she would have been taught "the sacred responsibilities of womanhood" (Woolf, 1975, p. 111). Orlando carries on her reflection and finds that a man's life is more dangerous and alive than a woman's; she resumes "all I can do, once I set foot on English soil, is to pour out tea and ask my lords how they like it. D' you take sugar? D' you take cream?" (Woolf, 1975, p. 111).

Orlando is horrified at the low idea men have on women. In a moment, she wakes up from her bewildered sex state and realizes that:

...to deny a woman teaching lest she may laugh at you; to be the slave of the frailest chit in petticoats, and yet go about as if you were the Lords of creation - Heavens!' she thought, 'what fools they make of us - what fools we are!'. (Woolf, 1975, p. 111)

In fact, in the end, there is no more a narrator and a character; they seem to melt one into the other to give us only one voice. Woolf's narrator dissolves with Orlando, the woman. What the narrator says is precisely what Orlando feels. There is no longer a third-person point of view since it melts into the first-person, and from time to time, there is the second-person point of view while the narrator intrudes to address the reader directly.

\section{Conclusion}

In Wives and Daughters, Gaskell told the story of Molly Gibson and the daily struggles in her life as a little girl. Yet, beyond that story, we have another one, which is embedded. It is the story of the development of the novel as a genre. This illustrates what Pittock (2010) explains as Gaskell's fiction depth and having sub-texts. Through the daily struggles of her main character, 
Elizabeth Gaskell illustrates the struggles of women writers for their right to be recognized, published, and read just like men writers were.

In Orlando, Virginia Woolf, as well, told us the story of Orlando, who lives over four centuries and draws lessons from each period he - then she - passes by. Orlando epitomises fiction, which passed through the different ages from a quasi-masculine, one-sex oriented culture to a new culture where women engaged in writing and took the pen and pain to reflect on their suffering better than a man writer would do for them.

Gaskell and Woolf managed to write through a social criticism a feminist literary one and to show that they drew the history of feminine writing from the beginning where the woman writer had no place in society - and therefore, no place in literature. They were hidden and unseen, but gradually, women got back their place in society. This explains the shift in the sex of Orlando from male to female, as well as Molly's evolution and personality change. What Gaskell and Woolf showed throughout their novels and their protagonists' development was the establishing of a female literary tradition. Through writing Gaskell and Woolf highlighted aspects of their society with which they disagreed with. Gaskell and Woolf's feminism is displayed throughout their respective novels. They defied the standards and criticised the norms imposed by a masculine society claiming, thus, for new ones, new norms that would grant women with the same rights given to men.

\section{About the Author}

Wassila Hamza Reguig Mouro is an Associate Professor at the Department of English, University of Aboubekr Belkaid Tlemcen. She holds a Doctorate in Literature and Civilization as well as a Habilitation. Her research interests are mostly literary and turn around Postmodernism (metafiction, intertextuality, dialogism and narration...), Women's writing, Postcolonial literature and the Victorian era. ORCid ID: https://orcid.org/0000-0002-5011-3551

\section{References}

Achour, C. and Bekkat, A. (2002) Clefs pour la lecture des récits: convergences critiques II, Algérie : Editions du Tell.

Bakhtin, M.M. (1981) The Dialogic Imagination: Four Essays, (Caryl Emerson and Michael Holquist Trans). Austin: University of Texas Press

Baldick, C. (2001). The Concise Dictionary of Literary Terms. New York: Oxford University Press.

Ballaster, R. (ed.). (2010). The History of Women's Writing: 1690 - 1750, Vol. 4. New York: Palgrave Macmillan

Barthes, R. (1974). S/Z. Oxford: Blackwell Publishing Ltd

Barthes, R. (1977). Image-Music-Text. London: Fontana

Blair, E. (2007). Virginia Woolf and the Nineteenth-Century Domestic Novel. Albany, New York: State University of New York Press

Briggs, J. (2006). Reading Virginia Woolf. Edinburgh: Edinburgh University Press 
Fallaize, E. (2007). Simone de Beauvoir and the Demystification of Woman. In G. Plain \& S. Sellers (eds.), A History of Feminist Literary Criticism (pp. 85-100). Cambridge: Cambridge University Press

Felber. L. (2001). Victorian Publishing and Mrs Gaskell's Works. Victorian Studies, 43 (2), 324-326. Indiana: Indiana University Press.

Foster, S. (2002). Elizabeth Gaskell: A Literary Life. UK: Palgrave Macmillan

Gaskell, E. (1986). Wives and Daughters. London: Penguin

Heilmann, A., \& Llewellyn, M. (2007). Metafiction and Metahistory in Contemporary Women's Writing. New York: Palgrave Macmillan

Hutcheon, L. (1980). Narcissistic Narrative: The Metafictional Paradox. Waterloo: Wilfrid Laurier University Press.

Lazar, M. M. (2007). Feminist Critical Discourse Analysis: Articulating a Feminist Discourse Praxis in Critical Discourse Studies, 4(2), 141-164. London: Routledge.

Lodge, D. (1992). The Art of Fiction. England: Penguin

Lorraine, C. (Ed) (2000). Encyclopedia of Feminist Literary Theories. London and New York: Routledge.

Mouro, W. (2014). Metafiction in the Feminine Novel: Elizabeth Gaskell's Wives and Daughters and Virginia Woolf's Orlando. Unpublished PhD Thesis. University of Tlemcen. Available at http://dspace.univ-tlemcen.dz/bitstream/112/5948/1/mourou-wassila.pdf

Mouro, W. (2013). Intertextuality in Elizabeth Gaskell's Wives and Daughters. International Journal of English and Literature (IJEL). 3 (5), 37-42. Available at https://archive.org/stream/6.Intextuality.full/6.\%20Intextuality.full_djvu.txt

Orlowski, V. (2017). Metafiction. Available at https://scholarblogs.emory.edu/postcolonialstudies/2014/06/21/metafiction/

Peters, J.D. (2002). Feminist Metafiction and the Evolution of the British Novel. Grainsville: University Press of Florida

Pittock, M. (2012). The Dove Ascending: The Case of Elizabeth Gaskell. English Studies, 81(6), 531-547. London: Routledge

Price, F. (2012). "A Great Deal of History": Romantic Women Writers and Historical Fiction. Women's Writing, 19(3), 259-272. London: Routledge

Price, F. (2012). "A Great Deal of History": Romantic Women Writers and Historical Fiction. Women's Writing, 19(3), 259-272. London: Routledge.

Showalter, E. (1998). Twenty Years on “A Literature of Their Own” Revisited in Novel: A Forum on Fiction, 31(3), 399-413. Durham: Duke University Press.

Stoneman, P. (2007). Gaskell, Gender, and the Family. In J. Matus (ed), The Cambridge Companion to Elizabeth Gaskell. Cambridge: Cambridge University Press

Watson, J. R. (1996). 'Round the Sofa': Elizabeth Gaskell Tells Stories. The yearbook of English Studies, 26, 89-99. University of Durham: Maney Publishing on behalf of Modern Humanities Research Association.

Waugh, P. (1984). Metafiction: The Theory and Practice of the Self-Conscious Fiction. London \& New York: Routledge

Arab World English Journal for Translation \& Literary Studies 
AWEJ for Translation \& Literary Studies Volume, 4 Number 4. October 2020

From Feminization of Fiction to Feminine Metafiction HAMZA REGUIG MOURO

Westman, K.E. (2001). The First 'Orlando': The Laugh of the Comic Spirit in Virginia Woolf's 'Friendships Gallery. Twentieth Century Literature, 47 (1), 39-71. New York: Hofstra University Press

Woolf, V. (1925). The Common Reader. London: Penguin. Available at http://gutenberg.net.au/ebooks03/0300031h.html

Woolf, V. (1975). Orlando. London: Penguin 